\title{
Gayrimenkul Yatırım Ortaklığı (GYO)'nın Gelişimi: Türkiye’de Bir GYO Olarak Emlak Konut
}

\author{
Oğuzhan ERDOĞAN* \\ Ahmet ÖZASLAN**
}

\begin{abstract}
ÖZ
Kırdan kente yaşanan göç, nüfus artışı, doğal afetler gibi unsurlar kentleşme sürecini belirlemektedir. Bu unsurlar, kentsel toprak üzerinde yapılaşma sürecini hızlandırmakta ve toprağı sermayenin çekim merkezleri haline getirmektedir. Kent içinde farklı gelir gruplarının ve yapıların olması, konut sunumunda çeşitlenmeyi ortaya çıkarmakta ve daha yaşanabilir mekânların oluşturulmasına zemin hazırlamaktadır. Bu çerçevede konut üretim sürecinde, inşaat sektörünün farklı aktörlerini de içine alan bir yöntem geliştirilmekte ve ülke ekonomisine katkısı için dünya genelinde gayrimenkul sektörüne yönelik finansman sistemleri oluşturulmaktadır. Gayrimenkul Yatırım Ortaklıkları (GYO)'nın kurulması da böyle bir gelişmenin ürünüdür. Buradaki amaç büyük çaplı konut projelerinin gerçekleştirilmesi için finansal kaynak yaratmaktır. Kaynak transferi sağlayan bu ortaklıkların kentsel gelişim ve dönüşüm sürecindeki ve ülke ekonomisinin gelişimindeki rolü büyüktür.

Bu çalışmada GYO’nun gelişimi ve mevcut durumu dünya ve Türkiye genelinde ortaya konmuş; konut üretimi açısından ülkemizde Toplu Konut İdaresi (TOKİ) iştiraki ile kurulan Emlak Konut GYO'nun işleyişi irdelenmiş; şirketin 2020 yılı faaliyet raporu verileri yardımıyla tamamlanan ve devam eden projeleri incelenmiştir.
\end{abstract}

Anahtar Kelimeler: Konut Üretimi, Gayrimenkul Yatırım Ortaklığı, TOKİ, Emlak Konut GYO

\section{Development of Real Estate Investment Trust (REITs): The Status of Emlak Konut as A REITs in TURKEY}

\begin{abstract}
Factors such as rural-to-urban migration, and natural disasters in the population report determined the urbanization process. These factors accelerate the process of building on the urban land and the land becomes the center of attraction of the capital. The presence of different income groups and structures within the city reveals the diversification in housing presentation and lays the foundation for the creation of more livable spaces. In the housing production process in the world, a financing system for the real estate sector is created to improve the functioning of the construction sector by a method that includes different actors and contributes to the country's economy. Such developments provide the establishment of Real Estate Investment Trusts (REITs); as a result, financial resources are created for the realization of large-scale housing projects. The role of these partnerships, which provide resource transfer, in the process of urban development and transformation and the development of the country's economy is important.

In this study is the development and current status of the REIT's in the world and Turkey; the operation of Emlak Konut REITs, which was established with the participation of the Housing Development Administration (TOKI) in our country and has the highest market value in terms of housing production, has been scrutinized; with the help of the company's 2020 annual report data, completed and ongoing projects were examined.
\end{abstract}

Keywords: Housing Production, Real Estate Investment Trusts, TOKI, Emlak Konut REITs

Geliş/Received: 15.07 .2021

Kabul/Accepted: 27.12 .2021

- Bu çalışma, insanlardan veri ve örnek toplamayı gerektiren, anket, inceleme, alan çalışması ve deney içeren çalışması kapsamına girmediğinden etik kurul onay belgesi gerektirmemektedir.

\footnotetext{
* Doç. Dr., Burdur Mehmet Akif Ersoy Üniversitesi, Bucak Belediyesi Başkan Yardımcısı, oerdogan@mehmetakif.edu.tr, ORCID ID: 0000-0033-8096-6887

** Dr., Süleyman Demirel Üniversitesi, İ.İ.B.F., Siyaset Bilimi ve Kamu Yönetimi, YÖK 100/2000 Kentsel Dönüşüm Çalışmaları Alanı, ahmetozaslan07@hotmail.com, ORCID ID: 0000-0002-0832-7337

(Makale Türü: Araştırma Makalesi)
} 


\section{Giriş}

1950’li yıllarda tarımda modernleşme, sanayileşmenin hızlanması ve şehirlere göçün artmasıyla gündeme gelen gecekondulaşma ve kaçak yapılaşma, özellikle büyük şehirlerin çevrelerinde ve çoğu kamu arazilerinin üzerinde ekonomik, sosyal, çevresel ve mekânsal sorunlara neden olmuştur. $\mathrm{Bu}$ sorunların ve konut talebinin giderilmesi için merkezi yönetim tarafından yasal mevzuatlar çıkarılmış ve ilgili kamu kurum ve kuruluşları görevlendirilmiştir. 1980’lere kadar kent çeperindeki boş arazilerin gecekondu mahallelerine dönüşme süreci devam etmiş ve 1980 sonrasında neoliberal politikalar özelleştirme, deregülasyon ve küreselleşme olgularını gündeme getirmiştir. Bu yaşanan küresel değişim süreci sermayenin hızlı bir şekilde kentsel arazi üzerindeki etkisini artırmıştır. Kamu yönetimi anlayışında yaşanan dönüşüm, kentsel gelişim ve konut üretiminde merkezi yönetimin yanında yerel yönetimleri ve özel sektörü önemli bir aktör haline getirmiştir. 1999 y1lında yaşanan Marmara Depremi’nin yarattığı yıkıcı etkinin yanında 2000'li yılların başında katılım, çok aktörlü karar alma süreci ve STK'ların güçlendirilmesi kentsel dönüşüme yönelik çabaları yoğunlaştırmıştır. Bu dönemde konut üretimi açısından TOKİ'nin yetkileri arttırılmış ve kurum bu görevini iştiraki ve gayrimenkul yatırım ortaklığı olan Emlak Konut GYO’nun desteğiyle yerine getirmeye başlamıştır.

1980'li y1llarda küreselleşme ve serbest piyasa ekonomisinin etkisiyle birlikte finansal piyasaların gelişmeye başlaması gayrimenkul yatırımlarına olan ilgiyi artırmıştır. Ülke ekonomisinde lokomotif etkiye sahip olan ve birçok alt sektörü besleyerek istihdam potansiyeli yaratan inşaat sektörü, ekonomik büyüme için önemli bir belirleyici haline gelmiştir. Konut üretimi ve satışını etkileyen gelir, kredi olanakları, faiz, döviz kuru gibi makroekonomik göstergeler gayrimenkul sektörünün yönünü belirlemektedir. Sektörde yaşanan problemler, düzensizlikler ve belirsizliklerin giderilmesi inşaat sektörü ile finansal piyasalar arasında kurumsallaşmanın önünü açmıştır. Bu gelişmeler doğrultusunda inşaat sektörü ile finansal piyasalar arasında ilişkinin geliştirilmesi için Gayrimenkul Yatırım Ortaklığ1 (GYO) dünyada ve ülkemizde önemli sermaye piyasası kurumları haline gelmiştir. Bu ortaklıklar geliştirilen büyük projelere yatırım yapmak, likidite sağlamak ve tasarrufları bir bütün olarak toplayarak projelerin sürdürülebilirliği için imkân sunmaktadır.

Bu çalışmada, imtiyazlı ortağı TOKİ olan ve Türkiye'de konut üretiminde köklü bir işletme olan Emlak Konut GYO A.Ş.'nin durumu gayrimenkul yatırım ortaklığının dünya ve Türkiye'deki gelişim süreci üzerinden ortaya konmaktadır. Ayrıca şirketin kurumsal olarak faaliyet alanları, iş modelleri ve 2020 yılı faaliyet rapor verileri 1şı̆̆ında konut satışları, tamamlanan ve devam eden projeleri incelenmektedir. 


\section{Gayrimenkul Yatırım Ortaklığı (GYO) Kavramı ve Gelişimi}

Gayrimenkul, bireysel yatırımcıların yanı sıra birçok kurumsal yatırım portföyünün önemli bir parçasıdır. Ancak gayrimenkul varlıklarının likidite ve verimlilik eksikliği ile yüksek sermayelendirme gibi bazı özelliklerinden dolayı özel yatırımcılar, doğrudan gayrimenkul sektörüne yatırım yapmamaktadır. Yatırımcıların çoğu için bu engeller, büyük ticari gayrimenkullerin mülkiyetine katılmalarını engellemektedir. Gayrimenkul yatırımcıları çözüm olarak, aralarında gayrimenkul yatırım fonlarının veya güvenin önemli rol oynadığı alternatif gayrimenkul yatırımlarına yönelmektedir (Mazurczak, 2011: 115).

Sermaye Piyasası Mevzuatında gayrimenkullerin menkul kıymetleştirilmesine yönelik iki ana model bulunmaktadır. Bunlar, Gayrimenkul Yatırım Ortaklıkları (GYO) ve Gayrimenkul Yatırım Fonları (GYF)'dır Nüve Capital, 2020). "Her iki farklı model de gayrimenkullerin menkul kıymetleştirilmesine, büyük ölçekli gayrimenkul yatırımlarına likidite sağlanmasına, ortaklık yapısı kullanılarak gayrimenkul yatırımlarının finanse edilmesine, yatırımcıların GYF katılma paylarını/GYO hisse senetlerini satın almak şartıyla bu yatırımlardan elde edilen gelirlerden faydalanmasına olanak tanıyan yatırım araçlarıdır (Nüve Capital, 2020).”

GYO; "Sermaye Piyasası Kanunu çerçevesinde Sermaye Piyasası Kurulu (SPK) tarafindan düzenlenen gayrimenkul yatırım ortaklıklarl, gayrimenkullere, gayrimenkul projelerine, gayrimenkule dayalı sermaye piyasası araçlarına ve gayrimenkule dayalı halklara yatırım yapmak suretiyle faaliyet gösteren özel bir portföy yönetim şirketidir (SPK, 2007: 4).” GYO, apartmanlar, ofis binaları, depolar, alışveriş merkezleri gibi gelir getirici gayrimenkul projelerini hayata geçiren ve işleten bir yapılanmadır (Mazurczak, 2011: 118). Başka bir ifadeyle GYO'lar sahibi, işletmecisi, proje geliştiricisi veya idarecisi olduğu gayrimenkullerden kira geliri ya da değer artışıyla kazanç sağlamayı hedefleyen ve gayrimenkule yatırım yapan şirketlerdir (Çikot, 2011: 23). GYO'ların payları borsada işlem görebilmektedir. GYO'lar portföylerinde bulunan gayrimenkullerden sağladıkları kar ve gelirleri temettü olarak ortaklarına aktarmaktadır (Çikot, 2011: 23). GYF ise, “nitelikli yatırımcılardan katılma payları karşılı̆̆ında toplanan paralarla, pay sahipleri hesabına inançlı mülkiyet esaslarına göre, SPK tarafindan belirlenmiş varllk ve işlemlerden oluşan portföyü işletmek amacıyla portföy ve gayrimenkul portföy yönetim şirketleri tarafindan süreli veya süresiz olarak kurulan ve tüzel kişiliği bulunmayan malvarlı̆̆ıdır (SPK, 2021)."

Genel olarak, gayrimenkul sektörüne kurumsal sermaye girişi sağlamak ve nitelikli projeler oluşturmak amaciyla kurulan GYO'lar, sektörde, yaşanan likidite sorununa çözüm sunmakta ve yatırımcılara ait tasarrufları tek bir çatı altında toplayarak, büyük ölçekli projelerin sürdürülebilirliğine olanak tanımaktadır (Milliyet Emlak, 2021). Kısaca GYO'lar, farklı yatırımcı türleri için geçerli olan yatırım aracı ve gayrimenkul piyasasının gelişimi için gerekli sermaye kaynağıdır (Mazurczak, 2011: 116). 
GYO'lar, gelişmişliğin ve ekonomik kalkınmanın bir göstergesi olarak daha çok gelişmiş ve gelişmekte olan ülkelerde uygulama alanı bulmaktadır. Genellikle hastane, park, alışveriş merkezi, arazi ve sosyal tesis projelerinde başvurulan GYO’ların günümüzde pek çok örneği vardır (Kandır ve Özhan, 2018: 32). "Uzun vadeli konut finansmanının uygulanması ile sektöre kurumsal sermaye girişini sağlayan GYO'lar, yeni sermaye piyasası aracı olarak piyasalarda etkin bir rol oynamaktadır. İlk başlarda daha çok kiralık gayrimenkul portföylerine yatırım yaparak büyüyen GYO şirketleri, zaman içinde daha çok gayrimenkul geliştiriciliği fonksiyonu üstlenmiştir (Reysaş GYO, 2021). Nitekim son yıllarda GYO şirketleri, yeni konut ve alışveriş merkezi yatırımlarına yönelmeye başlamıştır (TSKBGYO, 2021)."

İlk GYO yapısı 1960 yılında ABD Kongresi tarafından resmen tanınmıştır. 1961 yılında Massachusetts eyaletinde Real Estate Investment Trusts (REITs) olarak faaliyete başlayan GYO'lar (Kandır ve Özhan, 2018: 32), yönetici olarak birden fazla mütevelli ile birleşmemiş ve devredilebilir menfaat paylarına sahip bir şirket olarak tanımlanmıştır. Bireysel gayrimenkul yatırımcılarının doğrudan gayrimenkul sahipleri ile aynı avantajlardan faydalanmalarına izin verilmiştir. Çıkarılan yasayla, GYO’ların hissedarlara dağıtılan gelir üzerinden şirket düzeyinde vergilendirmeyi önlemesine izin verilmiş ve mevcut GYO yapısı için temel oluşturulmuştur. GYO yatırımlarındaki patlama, 1986 Vergi Reformu Yasası'ndan sonra başlamış ve 1993 yılında GYO’nun emeklilik fonlarına yatırım engelleri kaldırılmıştır. Bu reform, GYO’ların yüksek kaliteli gayrimenkul yatırımları yapma fırsatını arttırmıştır (Mazurczak, 2011: 116). Avrupa'da ise GYO tipi rejimlerin kurulması yeni bir fikir değildir. Avrupa'da GYO’lar ilk olarak 1969 yılında Hollanda'da kurulmuştur. Orta ve Güney Avrupa'daki diğer ülkeler ise bu ülkeleri takip etmiştir. GYO, Avustralya'da 1971 yılında, İngiltere ve Almanya'da ise 2007 yılında kendine yer bulmaya başlamıştır (EPRA, 2019). Avrupa Kamu Gayrimenkul Birliği’ne (EPRA) göre, 2011 yılında Avrupa, doğrudan ticari emlak piyasasında dünyanın temel varlıklarının \%42,3'ünü elinde tutmasına rağmen, küresel GYO piyasa değerinin sadece \%21,8'ini elinde tutmaktadır. 2011 yılında GYO rejimlerini uygulayan Avrupa ülkesi 13 iken (Mazurczak, 2011: 117), 2019 yılında bu sayı 15'e yükselmiştir. Aşağıdaki tabloda EPRA Global GYO Araştırması 2019'a göre, 15 AB ülkesinin GYO yapılanmasının kuruluş yılları, faaliyette bulunan GYO sayıları ve küresel GYO pazarından aldıkları yüzdelik payları verilmiştir (EPRA, 2019).

Tablo 1: AB üye ülkelerinde GYO'ların genel durumu

\begin{tabular}{|c|c|c|c|}
\hline Ülke & Kuruluş Yılı & GYO Sayısı & Küresel GYO Pazar Yüzdesi (\%) \\
\hline Belçika & 1995 & 17 & 1,02 \\
\hline Bulgaristan & 2004 & 29 & 0,00 \\
\hline Finlandiya & 2010 & -- & 0,00 \\
\hline
\end{tabular}




\begin{tabular}{|c|c|c|c|}
\hline Fransa & 2003 & 30 & 1,77 \\
\hline Almanya & 2007 & 5 & 0,25 \\
\hline Yunanistan & 1999 & 4 & 0,00 \\
\hline Macaristan & 2011 & -- & 0,00 \\
\hline İranda & 2013 & 4 & 0,25 \\
\hline İtalya & 2007 & 3 & 0,02 \\
\hline Litvanya & 2008 & -- & 0,00 \\
\hline Lüksemburg & 2007 & -- & 0,00 \\
\hline Hollanda & 1969 & 5 & 1,83 \\
\hline Portekiz & 2019 & -- & 0,00 \\
\hline İspanya & 2009 & 71 & 0,67 \\
\hline İngiltere & 2007 & 55 & 4,79 \\
\hline
\end{tabular}

Kaynak: EPRA, 2019.

Tablo 1'e göre, yukarıda da belirtildiği üzere tarihsel olarak GYO'lar ilk olarak Hollanda (1969) en son Portekiz (2019)'de faaliyete başlamıştır. Raporda Finlandiya, Macaristan, Litvanya, Lüksemburg ve Portekiz'de bulunan GYO sayıları hakkında veriye yer verilmemiştir. En yüksek gayrimenkul yatırım ortaklığı bulunan ülkeler İspanya ve İngiltere' dir. 2019 yılı itibariyle AB ülkelerinde bulunan GYO'ların küresel gayrimenkul piyasasından aldığı toplam pay \%10,6'dır. Tablo 2'de ise ülkeler bakımından GYO’nun olgunluk seviyesi ele alınmıştır.

Tablo 2: Ülkeler bakımından GYO’nun olgunluk aşamaları

\begin{tabular}{|c|c|c|c|}
\hline $\begin{array}{c}\text { Yeni Kurulan } \\
\text { (Olgunlaşmamış) }\end{array}$ & Gelişmeye Devam Eden & $\begin{array}{c}\text { Olgunlaşmaya Devam } \\
\text { Eden }\end{array}$ & Olgunlaşmış \\
\hline Bahreyn & Finlandiya & Avustralya & ABD \\
\hline Brezilya & İrlanda & Belçika & \\
\hline Kosta Rika & İtalya & Kanada & \\
\hline Bulgaristan & Malezya & Almanya & \\
\hline Yunanistan & Meksika & Hong Kong & \\
\hline Macaristan & Güney Afrika & Japonya & \\
\hline Hindistan & Güney Kore & Hollanda & \\
\hline İsrail & İspanya & Yeni Zelanda & \\
\hline Kenya & Türkiye & Singapur & \\
\hline Pakistan & Birleşik Arap Emirlikleri & İngiltere & \\
\hline Filipinler & & & \\
\hline Suudi Arabistan & & & \\
\hline Tayvan & & & \\
\hline Tayland & & & \\
\hline Vietnam & & & \\
\hline
\end{tabular}

Kaynak: EY Global Real Estate, 2017: 4.

Tablo 1'de AB ülkeleri özelinde açıklanmaya çalışılan GYO'ların durumu, Tablo 2'de AB ve 
diğer ülkeler açısından yeni kurulan ve olgunluk aşaması şeklinde sınıflandırılmıştır. Tablo 2'de Yunanistan, Macaristan, Brezilya gibi ülkeler olgunlaşmamış aşamada yer alırken Türkiye'nin de içinde bulunduğu Finlandiya, İrlanda ve İtalya gibi ülkeler gelişmeye devam eden aşamada yer almaktadır. Belçika, Fransa, Almanya, Hollanda ve İngiltere gibi ülkeler olgunlaşmaya devam eden 3. aşamada bulunmaktadır. Olgunlaşmış GYO'lara sahip tek ülke ise ABD'dir. Bunun sebebi, dünyada GYO'nun ilk kurulduğu ülke olması ve bu yapılanma ile ilgili eyalet yasalarının çıkarılarak uygulamaya başlanması olarak düşünülebilir.

\section{Türkiye'de GYO’nun Gelişimi ve Mevcut Durumu}

Günümüzde gayrimenkul piyasalarının en önemli kurumsal yatırımcıları olan GYO'ların geçmişi Türkiye'de görece olarak yenidir. Gayrimenkul yatırımları 1980'li yıllarda sermaye piyasalarının gelişmeye başlamasının etkisiyle kurumsal bir yapıya kavuşmaya ve fon yönetimi alanında faaliyet göstermeye başlamıştır. Bu kapsamda 1989 yılında konut sertifikası ve 1990 yılında arsa sertifikası arz edilmeye başlanmış ve bu sertifikaların uluslararası piyasalara ihracına izin veren düzenlemeler yapılmıştır. Ancak, bu uygulamalar amacına ulaşamamıştır. Zamanla bu alandaki yasal çerçeveyi çizecek olan mevzuatın hazırlanmasının ardından finansal piyasalar ile reel bir sektör olan inşaat sektörü arasındaki ilişkiler güçlendirilmiştir (Pınar, 2019: 76). Türkiye'de GYO'lar ile ilgili ilk hukuki düzenlemeler 1992 yılında Sermaye Piyasası Kanunu ve Vergi Kanunlarında yapılmıştır. Bu kanunda yapılan değişikliklerle "Yatırım Ortaklıkları sermaye piyasası araçları, gayrimenkul, altın ve diğer klymetli maden portföylerini işletmek amacıyla kurulan anonim ortakliklardır." ibaresi ile gayrimenkul yatırım ortaklıklarının kurulması sağlanmıştır (Tekşen Altaş, 2019: 25).

GYO'lar, Türk Ticaret Kanunu kapsamında yeni bir anonim şirket olarak ani usulde kurulabilmektedir. Daha öncesinde başka amaçla kurulmuş şirketler esas sözleşmelerini Sermaye Piyasası Kurulu'nun düzenlemelerine uygun olarak değiştirerek, GYO’ya dönüşebilmektedir. Her iki şekilde de gerçekleşebilen kurulma veya dönüşümün Kurul'ca uygun görülmesi şarttır (SPK, 2007: 10). $\mathrm{Bu}$ durum, Gayrimenkul Yatırım Ortaklıklarına İlişkin Esaslar Tebliği’nde (III-48.1), “Kurulca başvurunun uygun görülmesi halinde; altyapı faaliyetlerine ilişkin olarak ilgili makamlardan alınması gerekli diğer izin ve onaylara ilişkin mevzuat hükümleri sakl kalmak üzere, kuruluşta kuruluşun, dönüşümde ise esas sözleşme değişikliklerinin onaylanması talebi ile Gümrük ve Ticaret Bakanlı̆̆ı'na başvurulmaktadır şeklinde belirtilmiştir (Madde 8/2)."

Bakanlık kuruluş iznini verdikten sonra kuruluşun tescilinden sonra, yatırılan sermayeyi kullanarak şirket portföyünü oluşturmaktadır. Resmi olarak 1995 yılında SPK tarafından yasal düzenleme ile kurulmaya başlanan GYO'lar eski adıyla İstanbul Menkul Kıymetler Borsası'nda (IMKB) 1997 yılında işlem görmeye başlamıştır (Kandır ve Özhan, 2018: 32). Gayrimenkul sektöründe kurumsallaşmayı teşvik etmek amacıyla tanınan Kurumlar Vergisi istisnası ile bu finansman modeline 
ilgi artmıştır (TSKBGYO, 2021). Yapılan hukuki düzenlemelerle birlikte çeşitli GYO temsilcileri fikir birliğinde bulunarak gayrimenkul sektörünü geliştirmek, tanıtım ve temsilini sağlamak, sektörde kalite, kontrol ve eğitim konularında standartları belirlemek ve korumak amacıyla 1999 yılında Gayrimenkul Yatırım Ortaklıkları Derneği’ni (GYODER) kurmuştur (Çıkılı, 2010: 136). “GYODER, gayrimenkul sektörünün gelişimi için çözümler üretmeyi ve kurumsallaşmayı hızlandırmayı hedeflemekte, planlı ve düzenli kentleşme sürecinde metropollerde yerel yönetimler ve ilgili kamu kurumlarlyla kent içi rehabilitasyon ve dönüşüm planlarına katkıda bulunmakta, sektörün standartlarını oluşturmak ve GYO piyasasının tanitımı için toplantılar, seminerler, sempozyumlar düzenlemekte ve sektördeki iletişim ve bilgi alışverişinin artırılmasına katkı sağlamaktadır (Çıkılı, 2010: 136).”

“2004 yılında Sermaye Piyasası Mevzuatında GYO şirketlerine ilişkin hükümlerde önemli değişikliklere gidilmiş ve yatırım alanları genişletilerek yatırımcıların korunması ve kurumsal yönetim ilkelerinin uygulanmasına dair hükümler mevzuata eklenmiştir. 2009 yılının sonunda yapılan değişiklikle ise, GYO'lara kuruluşlarından itibaren halka arzlarına kadar tanınan süre kısaltılmış ve asgari halka açıklık oranı azaltılmıştır (TSKBGYO, 2021).” Sektörün ilk şirketleri Alarko Gayrimenkul Yatırım Ortaklığı A.Ş ve Vakıf Gayrimenkul Yatırım Ortaklığı A.Ş’dir. Bu şirketler ilk olarak 1997 y1lında hisse senetlerini satmaya başlamıştır (Tekşen Altaş, 2019: 25).

Türkiye'de 2020 yılı itibari ile 33 GYO faaliyet göstermektedir. Faaliyet gösteren gayrimenkul yatırım ortaklıklarının 2020 ilk çeyreği itibari ile piyasa değerleri Tablo 3’te gösterilmiştir. Buna göre, en yüksek piyasa değerine sahip olan GYO, Emlak-Konut GYO iken, en düşük piyasa değerine sahip olan GYO İdealist Gayrimenkul Yatırım Ortaklığıdır. Türkiye'de bulunan 33 GYO arasında Emlak Konut GYO’nun en büyük ve etkin GYO olmasının en önemli nedeni ise, devletin konut sorununa müdahalesi sonucu, bu GYO'nun devletin mevcut bankasından dönüşerek ortaya çıkmış olmasıdır (P1nar, 2019: 78).

Tablo 3: Türkiye'deki gayrimenkul yatırım ortaklıkları ve piyasa değerleri

\begin{tabular}{|c|c|}
\hline Ortaklı̆̆ın İsmi & Piyasa Değeri (TL) \\
\hline Emlak Konut Gayrimenkul Y.O. & 4.446 .000 .000 \\
\hline Yeni Gimat Gayrimenkul Y.O & 2.038 .579 .200 \\
\hline Torunlar Gayrimenkul Y.O. & 1.860 .000 .000 \\
\hline Reysaş Gayrimenkul Y.O. & 1.645 .740 .007 \\
\hline Doğuş Gayrimenkul Y.O. & 1.291 .510 .288 \\
\hline İş Gayrimenkul Y.O. & 1.217 .612 .500 \\
\hline Halk Gayrimenkul Y.O. & 1.132 .160 .000 \\
\hline Akiş Gayrimenkul Y.O. & 1.101 .035 .136 \\
\hline Özak Gayrimenkul Y.O. & 848.120 .000 \\
\hline Akmerkez Gayrimenkul Y.O & 791.487 .360 \\
\hline Nurol Gayrimenkul Y.O. & 778.800 .000 \\
\hline Sinpaş Gayrimenkul Y.O. & 777.142 .154 \\
\hline Alarko Gayrimenkul Y.O. & 727.720 .000 \\
\hline Servet Gayrimenkul Y.O. & 551.200 .000 \\
\hline Akfen Gayrimenkul Y.O. & 458.160 .000 \\
\hline Vakıf Gayrimenkul Y.O. & 450.800 .000 \\
\hline
\end{tabular}




\begin{tabular}{|c|c|}
\hline Tskb Gayrimenkul Y.O. & 450.000 .000 \\
\hline Panora Gayrimenkul Y.O & 362.790 .000 \\
\hline Atakule Gayrimenkul Y.O. & 288.750 .000 \\
\hline Özderici Gayrimenkul Y.O & 272.500 .000 \\
\hline Kiler Gayrimenkul Y.O. & 266.600 .000 \\
\hline Mistral Gayrimenkul Y.O. & 213.408 .945 \\
\hline Peker Gayrimenkul Y.O. & 197.370 .000 \\
\hline Deniz Gayrimenkul Y.O. & 158.500 .000 \\
\hline Körfez Gayrimenkul Y.O & 128.700 .000 \\
\hline Yeşil Gayrimenkul Y.O. & 91.695 .125 \\
\hline Yapı Kredi Koray Gayrimenkul Y.O. & 90.400 .000 \\
\hline Ata Gayrimenkul Y.O. & 88.587 .500 \\
\hline Diğer Gayrimenkul Y.O. & 313.437 .000 \\
\hline Toplam & 23.038 .805 .215 \\
\hline
\end{tabular}

Kaynak: GYODER, 2020: 67.

Türkiye'de GYO’lar, 6362 sayılı Sermaye Piyasası Kanunu'na uymakla yükümlüdür. 28 Mayıs 2013 tarihinde Sermaye Piyasas1 Kanunu'nun 48. ve 49. maddeleri dayanak alınarak hazırlanan Gayrimenkul Yatırım Ortaklıklarına İlişkin Esaslar Tebliği (III-48.1)'nde gayrimenkul yatırım ortaklığının tanımı "gayrimenkuller, gayrimenkul projeleri, gayrimenkule dayalı haklar, altyapı yatırım ve hizmetleri, sermaye piyasası araçları, Takasbank para piyasası ve ters repo işlemleri, Türk Lirası cinsinden vadeli mevduat veya katılma hesabl, yabanct para cinsinden vadeli ve vadesiz mevduat veya özel cari ve katılma hesapları ile iştirakler ve Kurulca belirlenecek diğer varlık ve haklardan oluşan portföyü işletmek amacıyla paylarını ihraç etmek üzere kurulan.... sermaye piyasası kurumudur." şeklinde belirtilmiştir (Madde 4). Ayrıca Tebliğin 22. maddesinde "Alım satım kârı veya kira geliri elde etmek amaciyla; arsa, arazi, konut, ofis, alışveriş merkezi, otel, lojistik merkezi, depo, park, hastane ve benzeri her türlü gayrimenkulü satın alabilir, satabilir, kiralayabilir, kiraya verebilir ve satın almayı veya satmayı vaad edebilirler." şeklinde yatırım faaliyetlerinin sınırlamalarının çerçevesi çizilmiştir. $\mathrm{Bu}$ doğrultuda gayrimenkul yatırım ortaklığının temel amacı, getiri oranı yüksek gayrimenkullere ve gayrimenkul projelerine yatırım yapmak, portföyündeki gayrimenkullerden kira geliri ve gayrimenkul alım satım kazancı elde etmek şeklinde ifade edilebilmektedir (SPK, 2021).

Portföyündeki gayrimenkullerin alım satımından kazanç elde eden GYO, yılsonunda bu kazançlarını ortaklarına temettü olarak dağıtabilmektedir. Yatırımcılar GYO'ların temettülerine ortak olmaları yanında, bu ortaklıkların paylarının borsada oluşan olası fiyat artışlarından da yararlanma olanağına sahiptirler. GYO'lar, sadece gayrimenkule dayalı portföyün işletilmesi kapsamında faaliyet gösterebilmektedir. Bunun sonucunda, GYO'lar aktiflerinde makine ve ekipman bulunduramaz, inşaat işlerini kendileri üstlenemez, proje yürütemezler. Ancak inşaatını başka şirketlerin gerçekleştirdiği projelere finansman sağlayabilirler (SPK, 2021).

GYO'lar ayrıca, teminat verebilme, borçlanma ve iştirak ile ilgili faaliyetlerde de 
bulunabilmektedir (SPK, 2007: 21). Gayrimenkul yatırım ortaklığı olarak kurulan veya esas sözleşme tadili yoluyla GYO’lara dönüşen ortaklıklar, paylarını halka arz yoluyla satabilmektedir. Asgari halka açıklık oranı \%25 iken halka açılma başvurusu için tanınan süre ise üç aydır. Halka arz sonrası durum, Gayrimenkul Yatırım Ortaklıklarına İlişkin Esaslar Tebliği (III-48.1)'nde "Halka arz sonrasında, ortaklı̆̆ın çıkarılmış sermayesinin asgari \%25'i oranındaki paylarının halka açık pay niteliğinde olması zorunludur." şeklinde düzenlenmiştir (Madde 11/2).

Gayrimenkul yatırım ortaklıklarının birden çok paydaşı bulunmaktadır. Temel olarak bir gayrimenkul yatırım ortaklığı organizasyonunda bulunan paydaşlar aşağıdaki gibidir (SPK, 2007: 8):

"İ̧̧letmeci Şirket: Ortaklığın mülkiyetinde bulunan veya kiralamış olduğu otel, hastane, alışveriş merkezi, iş merkezi, parklar, ticari depolar, konut siteleri, süpermarketler vb. nitelikteki gayrimenkulleri ticari amaçla işleten şirkettir. Şirket tarafından yapılacak yatırımlara, dağıtılacak kâra ve halka arza şirketin yönetimi karar vermektedir.

Müteahhit: GYO’larına ait gayrimenkul projelerinin inşaat işlerini gerçekleştirmeyi taahhüt eden gerçek ya da tüzel kişilerdir.

Danışman Şirket: Proje geliştirme ve kontrol hizmetleri de dâhil olmak üzere, ortaklık portföyünün geliştirilmesi ve alternatif yatırım olanaklarının araştırılmasına ilişkin bu işlerde uzmanlaşmış şirketlerden danışmanlık hizmeti alınmaktadır.

Gayrimenkul Değerleme Şirketi: GYO portföyünde yer alan gayrimenkullerin, gayrimenkul projelerinin ve gayrimenkule dayalı hakların rayiç değerlerini ve kira rayiçlerini belirleme konusunda hizmet veren şirketlerdir.

Hissedarlar: GYO hisselerine sahip, kârdan pay alan ancak yönetimde yer almayan kişilerdir.”

Yukarıda belirtilen GYO paydaşlarının aralarındaki etkileşim, koordinasyon ve faaliyetleri Şekil 1'de gösterilmiştir.

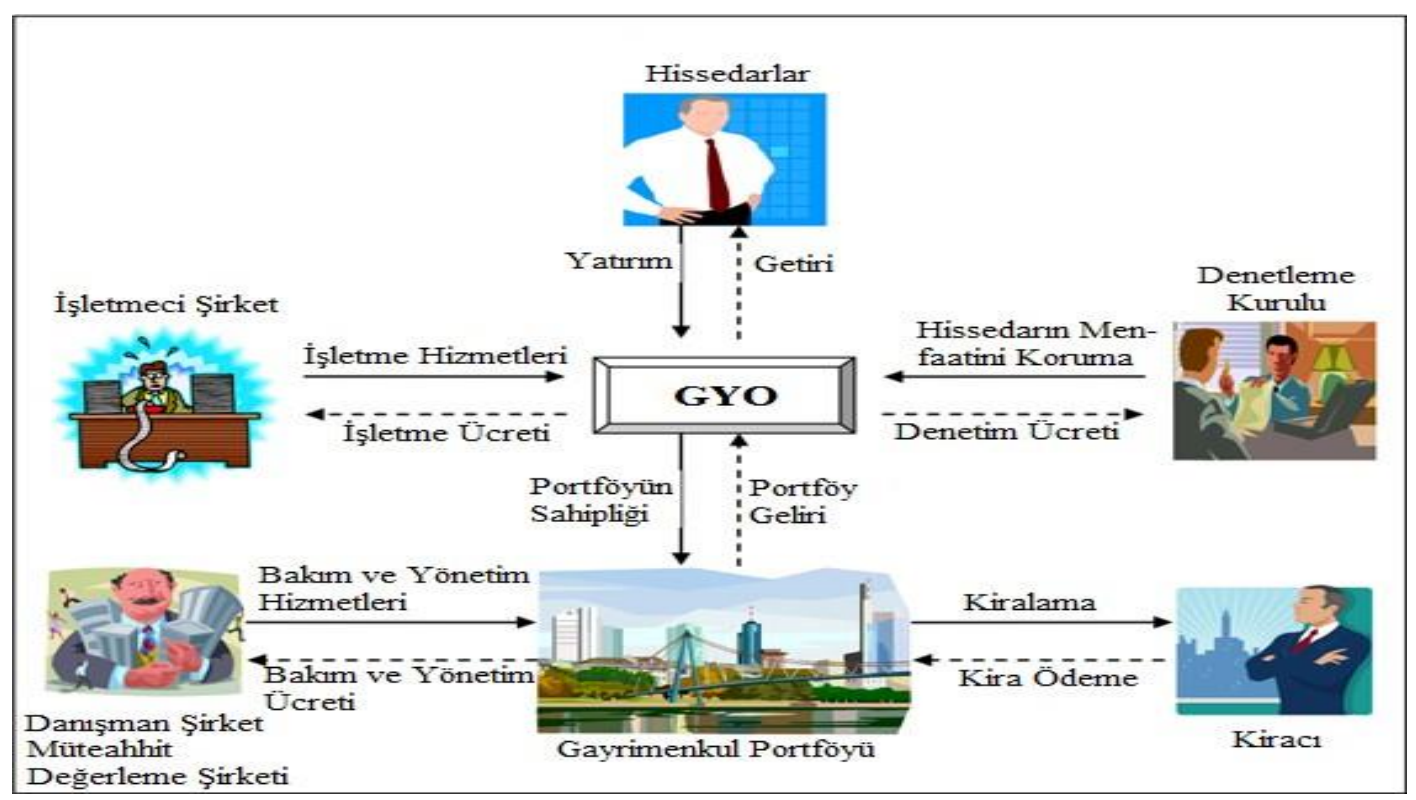


Şekil 1: Gayrimenkul yatırım ortaklıklarının paydaşları (Dusuki, 2008: 28; Tekşen Altaş, 2019: 16).

Türkiye'deki Sermaye Piyasası Kanunu düzenlemelerine göre, GYO bir anonim şirkettir. Genel olarak GYO'lar gayrimenkullere, gayrimenkullere dayalı sermaye piyasası araçlarına, gayrimenkul projelerine, gayrimenkullere dayalı haklara ve sermaye piyasası araçlarına yatırım yapabilmekte ve belirli projeleri üstlenmek için olağan ortaklıklar kurabilmektedir (Erol ve Ozuturk, 2011: 76). Bu ortaklıklar gerçek kişiler, kamu veya özel kuruluşlar, yerli veya yabancı ortaklıklar şeklinde gerçekleşmektedir. GYO, düzenlemelerde öngörülen şartları yerine getirdikten sonra paylarını SPK'ya tescil ve hisselerini halka arz etmektedir. Halka arz edilen hisseler aracı kuruluşlar ve yatırım bankaları tarafından talep edilerek borsada işlem görmeye başlamaktadır. Yukarıda da belirtildiği üzere yatırımcılar hisse senedi alım/satımı ile hem kar elde etmekte hem de diğer ortaklarına temettü olarak dağıtmaktadır. Türkiye'deki GYO'ların portföy kazançları, temettü dağıtmalarına bakılmaksızın kurumsal vergiden muaftır. GYO'lar Kurul'a kayıtlıysa ve tüm yasal koşulları yerine getiriyorsa, bu muafiyetten yararlanırlar. Yatırımcı düzeyinde hisse satışı, yerli ve yabancı yatırımcılar için stopaj vergisinin \%0'ına tabidir. Yerli yatırımcılar için, temettülerin $1 / 2$ 'si vergiden muaftır ve Gelir Kanununda belirlenen gelir tutarını aşarsa, gelir beyan edilmektedir (Erol ve Ozuturk, 2011: 76-77).

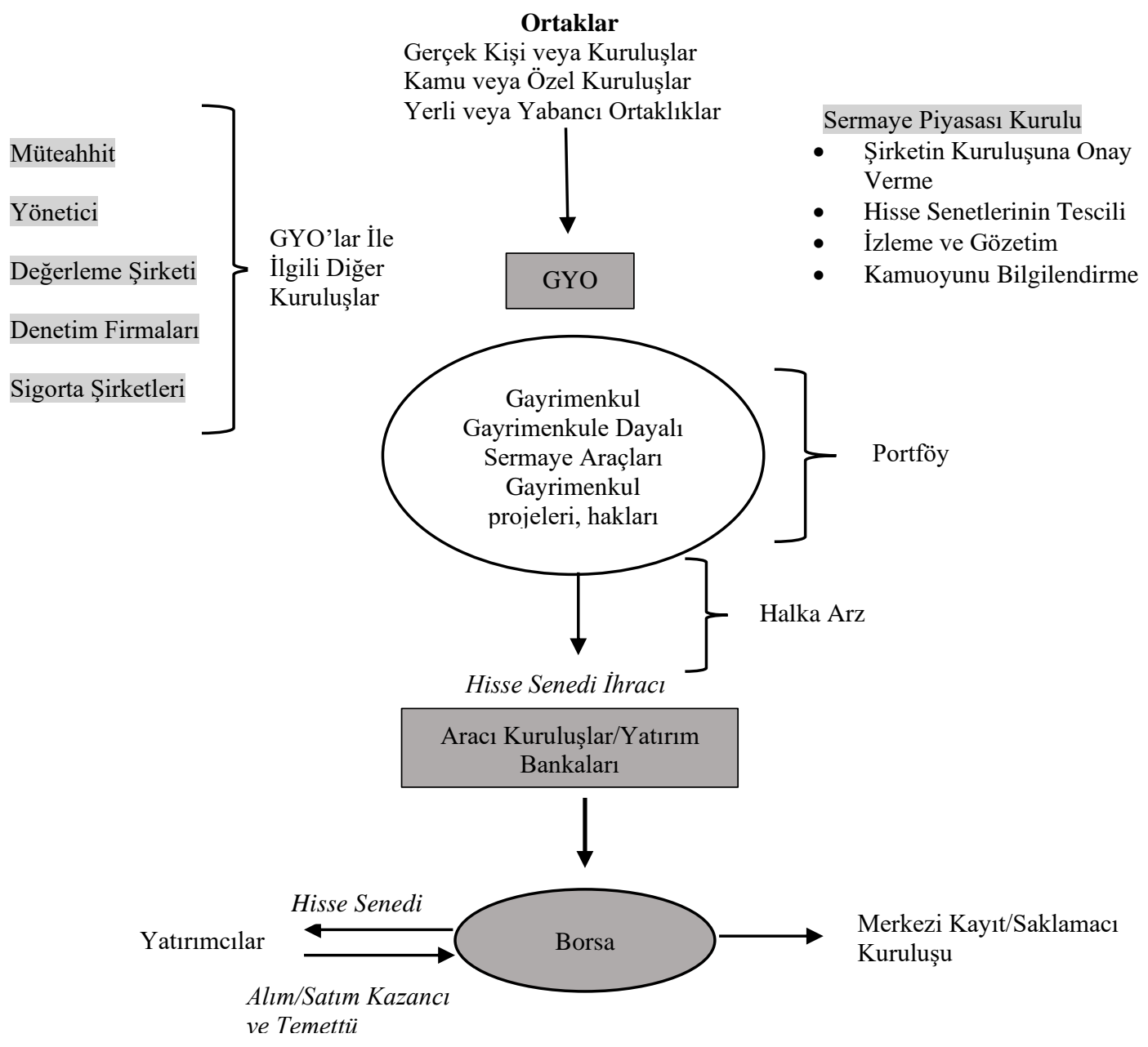


Şekil 2: Türkiye'de GYO’ların yasal ve işlevsel yapısı (Erol ve Ozuturk, 2011: 77).

Türkiye'de GYO'ların yasal ve işlevsel yapısı şekil 2'de incelenmiştir.

\section{Emlak Konut GYO}

2020 yılı itibariyle piyasa değeri açısından Türkiye'deki en büyük gayrimenkul yatırım ortaklığ1 Emlak Konut GYO’dur. TOKİ iştiraki ile kurulan Emlak Konut GYO’nun tarihsel serüveni çok eski bir tarihe dayanmaktadır. Devlet, konut üretim biçiminin farklı bir boyutta ele alınması için 1937 yılında Emlak ve Eytam Bankası içeriğinde Emlak Bank Yapı Ltd. Şti. kurmuştur. Şirketin faaliyete başlamasıyla, 1945 yılında Türkiye'de yapılan ilk toplu konut projesi "Memurin Apartmanları Saraçoğlu Mahallesi'dir (Pınar, 2009: 78). 1950'li yıllarda tarımın makineleşmesi ve özellikle traktör kullanımının artması genç işgücü nüfusun kırsal alanda yoğunlaşmasına yol açmış ve Ankara, İstanbul ve İzmir gibi büyük illere göçü artırmıştır. Kentlerde artan nüfusun barınma talebine karşıllık gelen konut sayısının yetersizliği büyük konut açıklarıyla sonuçlanmıştır. Konut açığının yasal olarak giderilmesi için Kooperatifler ve Emlak Bankası konut üretimini artırmıştır. Kentsel nüfusun içinde yer alan yoksul gruplar konut edinimini yasadışı olarak gidermeye çalışmıştır. Bunun sonucunda, kentin çeperlerinde ve sanayi alanlarının yakınında gecekondulaşma yoğunlaşmıştır. Gecekonduların yaygınlaşması metropol kentlerin, kentsel büyümelerine yön veren temel bir oluşum olarak görülmüştür.

Türkiye'de gayrimenkul sektörünü geliştirmek amacıyla 1953 yılında ilk şirket olarak Ankara İmar Ltd. Şti. kurulmuş, 1987 yılında ise Ankara İmar ile Türkiye İnşaat Malzemeleri (TİMLO) ile birleşerek İnşaat ve İmar A.Ş. adını almıştır. İnşaat ve İmar A.Ş.; devlet bankası Anadolu Bankası ile birleşip 1985'te toplu konut projesine başlayarak 1987'de Emlak Kredi Bankası adını almıştır. Bir inşaat şirketi olan Eska ile anlaşıp 1989 yılında Anatepe arazisinde 850 konutla toplu konut uygulamasına başlamıştır. 1988 yılı sonrası Emlak Bankası yürüttüğü projelerin en büyüklerinden olan ve "Anatepe Uydukent Projesi" olarak bilinirken akabinde "Ataşehir" adını alan proje, Anadolu Bankası'na devredilmiştir. Banka kaynakları üzerinde ciddi baskılar yaratan proje en sonunda 2001 yılında Emlak Bankasının tasfiye edilmesiyle birlikte proje üzerindeki haklar ve yetkiler TOKİ ve Emlak Gayrimenkul Yatırım Ortaklığı A.Ş.'ye devredilmiştir (Pınar, 2009: 79). 2002 yılında Emlak Konut, gayrimenkul yatırım ortaklığına dönüşmüştür. GYO olmasıyla beraber Emlak Konut; tasarım alanında, çevreye odaklı teknolojileri içinde barındıran, kente değer katan ve katma değer sağlayan niteliklerde projelerin uygulamasında yer almıştır (Emlak konut, 2021).

2006 yılında Emlak Gayrimenkul Yatırım Ortaklığg A.Ş. olan unvanı, Emlak Konut Gayrimenkul Yatırım Ortaklığı A.Ş. olarak değiştirilmiştir. Emlak Konut GYO büyüme politikaları çerçevesinde 2010 yılında ilk, 2013 yılında ise ikinci halka arzını gerçekleştirmiştir. Halka arzlar hem bireysel yatırımcı talebi rekoru kırması hem de Cumhuriyet tarihimizin en büyük 5. halka arzı olması sebebiyle önemlidir. 2013 yılındaki ikinci halka arzında hisse senetlerine 2-3 kat talep olmuş ve 20 farklı 
ülkeden 100'ün üzerinde uluslararası yatırımcı ilgi göstermiştir. Emlak Konut GYO'nun halka arzı, Orta ve Doğu Avrupa, Ortadoğu ve Afrika bölgesinde sermaye artırımı şeklinde yapılan yılın en büyük halka arzı olmuştur (Emlak Konut GYO, 2019: 10). Ayrıca, bu ikinci halka arz son 5 yılda Avrupa'da gayrimenkul alanında yapılan en büyük halka arzdır. Halka arzlarla büyüyen Emlak Konut GYO, 3,8 milyar liralık ödenmiş sermayesi ve ulaştığı 31 Aralık 2019 itibariyle 24,2 milyar liralık aktif toplamıyla Türkiye'nin en önemli şirketlerinden biri olmuştur (Emlak konut, 2021).

Tablo 4: Emlak Konut GYO’nun Kilometre Taşları

\begin{tabular}{|c|c|}
\hline 1953-54 & $\begin{array}{l}\text { Türkiye'de gayrimenkul geliştirmek amacıyla “Ankara İmar ile Türkiye İnşaat } \\
\text { Malzemeleri (TİMLO)” kurulmuştur. }\end{array}$ \\
\hline 1987 & “Ankara İmar” ile birleşerek adı "İnşaat ve İmar A.Ş” şeklinde değişmiştir. \\
\hline 1990 & $\begin{array}{l}\text { "Türkiye Emlak Bankası"nın bir iştiraki olan Emlak Yapı A.Ş ile birleşmesi sonucu } \\
\text { adı "Emlak Konut A.Ş"” olarak değişmiştir. }\end{array}$ \\
\hline 2001 & Emlak Bankası'nın kontrolünde olan hisseleri TOKİye devredilmiştir. \\
\hline 2002 & $\begin{array}{c}\text { Emlak Bankası'na ait hisselerin TOKI'ye devrinin ardından GYO statüsünü } \\
\text { kazanmıștır. }\end{array}$ \\
\hline 2007 & $\begin{array}{l}\text { Emlak Konut'un, diğer GYO'lara uygulanan tüm sermaye piyasası } \\
\text { düzenlemelerinden kısmen muaf tutan kanun (vergi muafiyeti dışında) kabul } \\
\text { edilmiştir. }\end{array}$ \\
\hline 2010 & Birinci Halka arz \%25 Sermaye Artırımı ile 2 Milyar 500 Milyon TL olmuştur. \\
\hline 2013 & \%50,4 Halka Açıklık ile İkinci Halka Arz 3 Milyar 800 Milyon TL olmuştur. \\
\hline 2020 & $\begin{array}{l}\text { Türkiye'nin en büyük GYO’su, geliştirilmiş } 146 \text { proje-131 bin bağımsız bölümü ile } \\
28,64 \text { Milyar TL değerine ulaşmış, toplam varlık } 15.1 \text { Milyar TL satış elde etmiştir. }\end{array}$ \\
\hline 2023 & 250.000 bağımsız bölüm hedefi belirlenmiştir. \\
\hline
\end{tabular}

Kaynak: Emlak Konut GYO, 2020: 12.

Türkiye'de gayrimenkul sektörünün gelişiminde çok önemli bir rolü olan, Emlak Konut GYO’nun vizyonu: “Yönetim anlayışıın ve kalite standartlarını sürekli gelişstirerek, yurt içi gayrimenkul sektöründeki konumunu devam ettirmek ve daha ileriye taşımak. Planlı, nitelikli ve çevreye duyarlı şehircilik anlayışını, uluslararası kriterlerde daha yukarıya taşıyarak dünyadaki sayılı gayrimenkul yatırım ortaklıkları arasına girmek. Bugüne kadar gerçekleştirilen ve gerçekleştirilmekte olan konut + ticari ünite sayısını, 2023 yıl sonuna kadar 250 bine çıkarmak" iken; misyonu: "Yurt içi gayrimenkul sektörüne yön veren öncü kuruluşlardan birisi olarak, sektördeki gelişmeleri ve yenilikleri yakından takip etmek. Toplumsal değerleri ve müssteri memnuniyetini önemseyerek huzurlu ve güvenle yaşanabilecek mekânların olduğu, çağdaş şehircilik anlayışına sahip, planll, nitelikli ve çevreye duyarlı yerleşim merkezleri üretmek. Personelin ve hissedarların, maddi ve manevi memnuniyetini önemsemek" şeklindedir (Emlak Konut GYO, 2019: 4). Belirlenen vizyon ve misyon kapsamında Emlak Konut GYO’nun temel amac1, insan hayatına konfor katacak, çevreye duyarlı, modern kentler kurmaktır. Bu amaçla birlikte Emlak Konut, sektörüne pek çok yenilik getiren uygulamaların başında yer almaktadır (www.emlakkonut.com). Emlak Konut GYO 2019 Faaliyet Raporu'nda şirketin amacı ve faaliyet 
konusu aşağıdaki gibi belirtilmiştir. Bunlar:

“Gayrimenkul projelerinde büyük kısmı konut olmak üzere aynı zamanda ticari bölümler, eğitim birimleri, sosyal donatılar, altyapı, yol ve her türlü çevre düzenlemesinin gerçekleştirilmek,

Geliştirilen projelerin inşaat kontrolörlüğünü yapılmak,

Yapılan bağımsız bölümlerin pazarlamak ve satışını gerçekleştirmektir.”

Emlak Konut GYO'nun sermaye ve ortaklık yapısının \%49,37'lik kısmı TOKİ A ve B Grubuna aitken, \%50,6'lık kısmı ise halka açıktır. Ortaklık türü açısından TOKİ B Grubu, Halka Açıklık ve Diğer kategorisi hamiline iken, TOKİ A Grubunun ortaklık türü imtiyazlıdır. 2020 verilerine göre, \%50,6'lık pay ile en yüksek ortaklığa sahip olan halka açıklığın tutarı 1.925.787.49 TL'dir. Sırasıyla TOKİ B Grubu (\%42,7) 1.621.460.838 TL, TOKI A Grubu $(\% 6,67)$ 253.369.919 TL ve Diğer $(\%<1)$ kategorisindeki ortaklık yapısından elde edilen tutar ise 50.455,16'TL'dir (Pınar, 2019: 89).

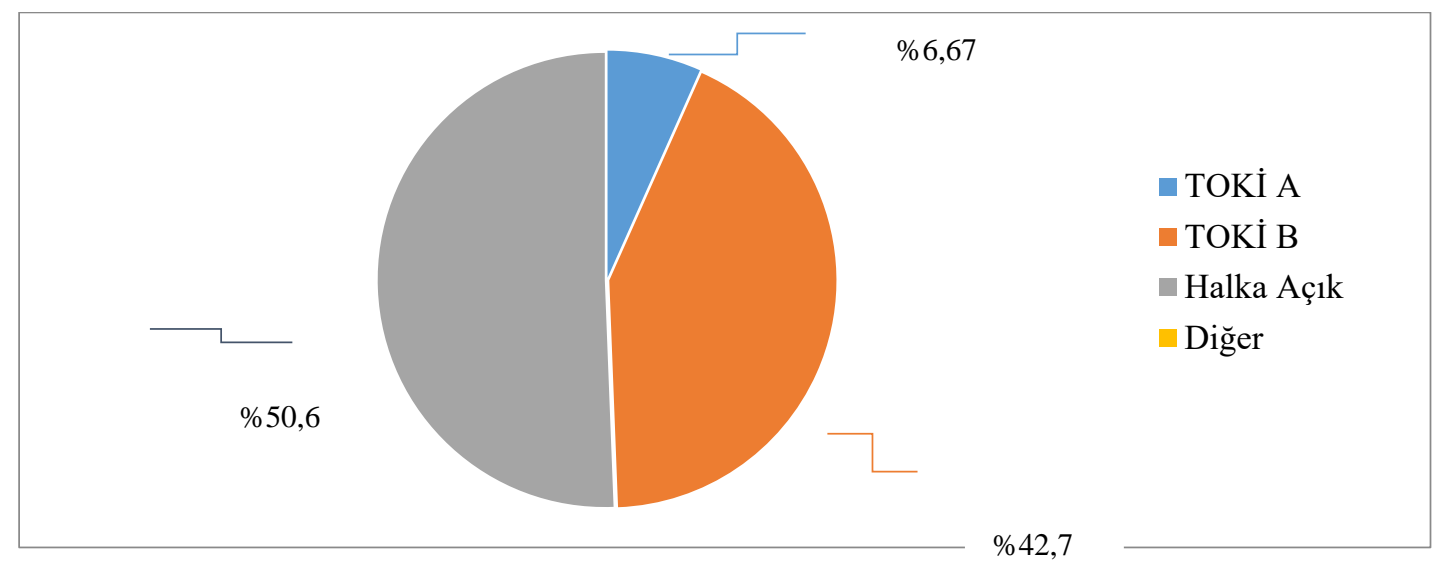

Şekil 3: Emlak konut GYO’nun sermaye ve ortaklı payları (Emlak Konut GYO, 2020:13).

Emlak Konut GYO planlanan hedef ve stratejilere ulaşmak için iki farklı iş modeli uygulamaktadır. Bu iş modellerinin birincisi "Gelir Paylaşımı Modeli”, ikincisi ise "Anahtar Teslimi Götürü Bedel Proje Modeli”dir. Gelir paylaşımı modeli, daha çok orta ve üst gelir grubuna yönelik projelerde öne çıkmaktadır. Şirket, gerektiğinde gelir paylaşım modeline göre geliştirilen projelerden, projenin devamı sürecinde veya sonrasında bağımsız bölüm satın alabilmekte veya projenin sonunda yüklenici firma ile bağımsız bölüm paylaşımı yapabilmektedir (Emlak Konut GYO, 2020: 11).

Tablo 5: Gelir paylaşımı modelinin işleyişi

\begin{tabular}{l} 
Yüklenici, Emlak Konut'a projenin geliştirildiği arazinin değerleme değerine eşit ya da bu değerden \\
daha yüksek olmak üzere en düşük miktarda gelir sağlar. \\
En sondaki gelir paylaşımı oranı başlangıçta belirlenir. \\
\hline \multicolumn{1}{c|}{ Yüklenici Sorumlulukları } \\
Proje geliştirilir, finansmandan satış ve fiyatlandırmaya kadar, tüm süreçten sorumludur. Tasarım, \\
inşaat ve pazarlama malzemeleri Emlak Konut'un onayına tabidir. \\
İnşaatın teknik kontrolünü Emlak Konut gerçekleştirir.
\end{tabular}




\section{Risk Transferi}

Bütün geliştirme sürecine ilişkin olarak birçok geliştirme ve finansman riskini yüklenici üstlenir. Emlak Konut başta projeye arazi katkısı ve olası bina stokları olmak üzere sınırlı finansman ve geliştirme riski üstlenir.

Emlak Konut’a büyük ölçekli projeler yürütme esnekliği tanır.

Kaynak: Emlak Konut GYO, 2018: 72.

Anahtar teslimi modelinde ise yüklenici seçilerek iş, geçerli en düşük teklifler arasında en uygun istekliye verilmektedir. Projenin geliştirilmesiyle ilgili tüm riskleri ve sorumlulukları Emlak Konut üstlenmektedir. Ayrıca, bağımsız bölümlerin satışından elde edilen gelirin tamamı Emlak Konut'a kalmaktadır (Emlak Konut GYO, 2020: 11).

Tablo 6: Anahtar teslim modelinin işleyişi

\begin{tabular}{|c|}
\hline $\begin{array}{l}\text { Gelirler } \\
\text { Konut ve ticari birimlerin satışlarından elde edilen gelirin tümü Emlak Konut'a aittir. } \\
\text { Yükleniciye projenin fiziki olarak geliştirilmesine bağlı olarak hakkediş ödemeleri yapılır. }\end{array}$ \\
\hline $\begin{array}{c}\text { Yüklenici Seçimi } \\
\text { Yapılacak ihale yoluyla en düşük teklifler arasından en uygun yüklenici seçilir. }\end{array}$ \\
\hline
\end{tabular}

Kaynak: Emlak Konut GYO, 2018: 72.

Emlak Konut GYO’nun Türkiye'de en yüksek piyasa değerine sahip firma olmasının altında yatan sebep, satış modelleri ve kuruma duyulan güvendir. Şirket başarısının boyutları iş modelleri, projeler, karlılık, satış, beklenti ile ilgili rakamları aşağıdaki tabloda görülmektedir. Buna göre, gelir paylaşımı modelinin Emlak Konut GYO’nun uygulamada daha çok kullandığı bir yöntem olduğu ve önemli bir katma değer yarattı̆̆ söylenebilmektedir.

Tablo 7: Emlak konut GYO’nun özet rakamsal büyüklükleri

\begin{tabular}{|c|c|c|c|c|}
\hline $\begin{array}{c}\text { Gelir Paylaşımı } \\
\text { Satıș Toplam Geliri } \\
75 \text { Milyar }\end{array}$ & $\begin{array}{c}\text { Anahtar Teslimi } \\
\text { İşleri Yapım Bedeli } \\
11,1 \text { Milyar }\end{array}$ & $\begin{array}{c}\text { 5 Yıllık Toplam } \\
\text { Kar Hedefi } \\
4,15 \text { Milyar }\end{array}$ & $\begin{array}{c}\text { Güçlü Ön } \\
\text { Satış Oranı } \\
2021 \text { 'de \%72 }\end{array}$ & $\begin{array}{c}\text { Toplam } \\
\text { Geliştirilen } \\
\text { Bölüm Sayısı } \\
131 \text { Bin }\end{array}$ \\
\hline $\begin{array}{c}\text { Başarılyla } \\
\text { Yürütülen/ Teslim } \\
\text { Edilen Proje } \\
87\end{array}$ & $\begin{array}{c}\text { Yürütülen/ Teslim } \\
\text { Edilen Proje } \\
59\end{array}$ & & 2022 'de \%57 & \\
\hline
\end{tabular}

Kaynak: Emlak Konut GYO, 2020: 19.

Emlak Konut GYO'nun üretmiş olduğu konut ve ticari alanların satış işlemlerinin gerçekleştirilmesi için farklı tip iş yapma modelleri uygulanmaktadır. Bu üretim ve satış stratejisine bağlı olarak şirket kar sağlamayı amaç edinerek, yıllar içinde konut piyasasında önemli bir aktör haline 
gelmiştir. Aşağıda şirketin yıllar içinde gerçekleştirdiği bağımsız bölümlerin (konut ve ticari birim) satış miktarı ve satılan bağımsız bölümlerden elde edilen gelir miktarı verilmiştir.

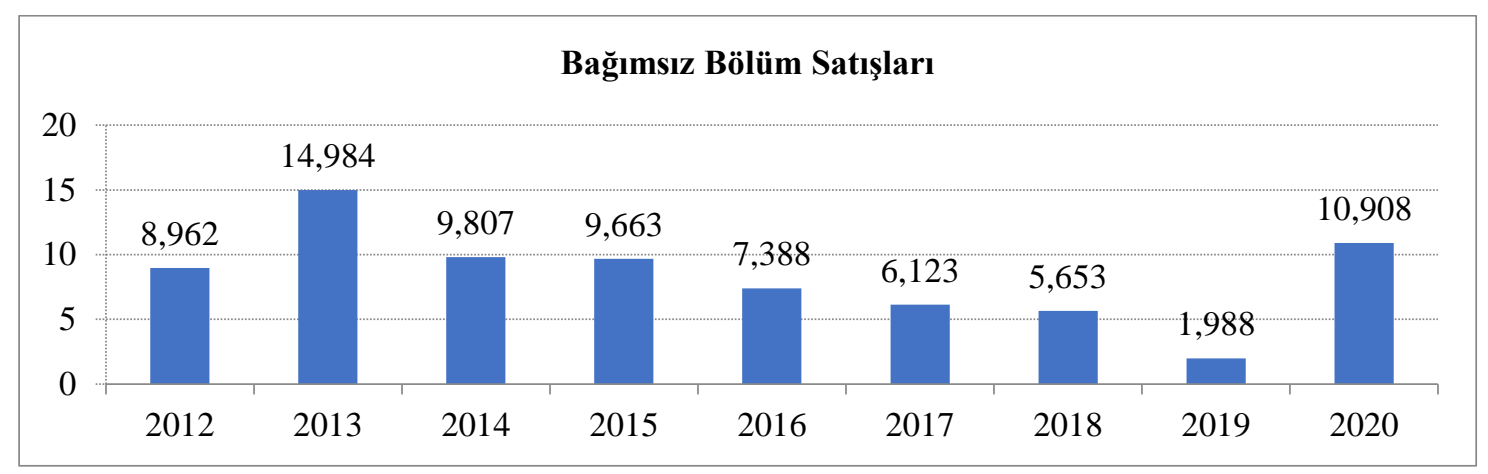

Şekil 4: Yıllar itibariyle bağımsız bölüm satışları (Adet) (Emlak Konut GYO, 2020: 21).

Yukarıdaki şekle göre son 9 yılda en yüksek satışını 2013’te gerçekleştiren Emlak Konut GYO’nun satış miktarları 2015 yılından itibaren düşüş eğilimi göstermektedir. Özellikle 2020 yılında yükselen faiz oranları ve pandemi sürecine rağmen yüksek satış gerçekleşmiştir. Satışa hazır olan konut ve ticari alanların satış miktarının azalmasına rağmen elde edilen satış değerinin yükseldiği de görülmektedir. 2020 yılında tüm zamanların en yüksek satış geliri elde edilmiştir. Emlak Konut GYO'nun geliştirmiş olduğu bağımsız bölümler hem yerli hem de yabancı uyruklu vatandaşlar tarafından satın alınmaktadır. Emlak Konut GYO 2021 yılı için, toplam satış değerini 11 milyar TL ve net karını 1,11 milyar TL olarak hedeflemiştir.

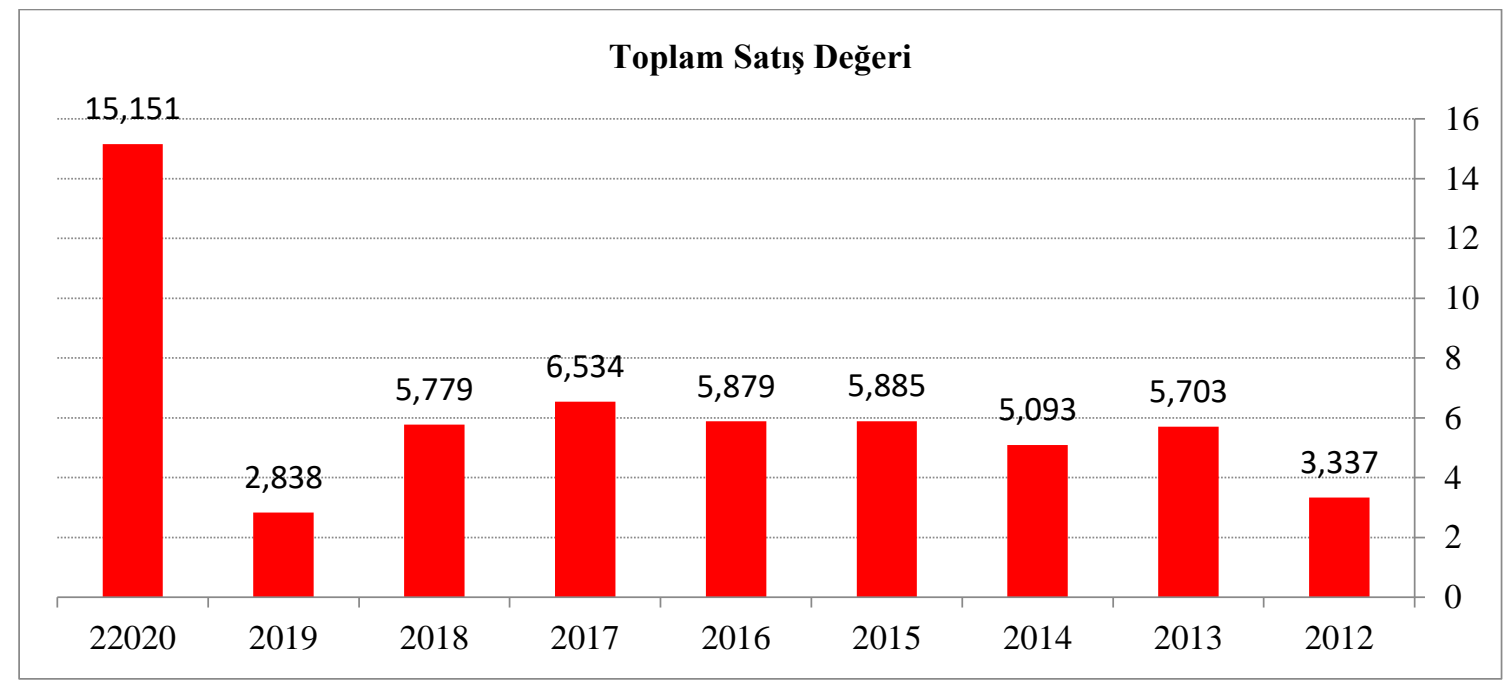

Şekil 5: Yıllar itibariyle toplam satış değeri (Milyon TL) (Emlak Konut GYO, 2020: 21).

Yıllar itibariyle satılan bağımsız bölüm miktarı ile bunlardan elde edilen gelir arasındaki farkın giderek açılmasının sebeplerini ortaya koyabilmek için ülkemizdeki konut piyasasının işleyişini anlamak gerekmektedir. İnsanoğlunun temel ihtiyaçları arasında yer alan barınma ihtiyacı konut talebini etkileyen en önemli sebeplerden birisidir. Ayrıca bireyler elde ettiği gelirin bir kısmını tasarruf ederek gayrimenkul yatırımına dönüştürmektedir. "Nüfusun büyümesi, kentleşmenin artması, kentlerdeki hane 
halkı sayısının azalması ve yaşanan göçler Türkiye'de konut ihtiyacını artırmaktadır. Demografinin değiş̧imi; evlenme, boşanma, yalnı yaşama, çalışma alışkanlıklarının değişimi gibi nedenler ile daha fazla erişilebilir konuta ihtiyaç duyulmaktadır. Kentsel dönüşüm ve alt yapı çalışmalarının sürmesi ve gayrimenkul sektörü aktörlerinin Türkiye'nin konut alanındaki ihtiyaçlarını belirlemesi sektörü daha da hareketlendirmektedir (GYODER, 2014: 25).”

Ülke ekonomisinin büyümesine katkı sağlayan ve birçok sektörü doğrudan ve dolaylı olarak harekete geçiren inşaat ve gayrimenkul sektörünün sürekliliği belli başlı makroekonomik göstergelere bağlıdır. Konut piyasasında bir konutun fiyatı, konut arz ve talep dengesi tarafından belirlenmektedir. Kısa dönemde, konut arzı neredeyse sabit olduğundan konut fiyatlarını belirleyen temel değişken konut talebindeki artış ya da azalıştır. Dolayısıyla, kısa dönemde konuta olan talebin artması konut fiyatlarını arttırmakta, talebin azalması ise fiyatları azaltmaktadır. Konut sektörü açısından inşaat maliyetlerinde yaşanan değişimler de arz-talep dengesini etkilemektedir. Maliyetlerin artması sadece kâr marjını sınırlamamakta, beklentileri ve yatırım kararlarını da etkilemektedir. Özellikle inşaat ve ilgili diğer alt sektörlerdeki ana girdi fiyatlarındaki artışı etkileyen en önemli unsur artan döviz fiyatları ile birlikte yükselen faiz oranlarıdır (Emlak Konut GYO, 2018: 109-119). "Konut sektörünün yönünü belirleyen en önemli değiş̧kenlerden birisi de kredi koşulları ve kredi faiz oranlarıdır. Özellikle orta gelir grubuna yönelik esnek ödeme imkânı sağlayan krediler konut talebini büyük oranda etkilemektedir. Faiz oranı ise konut piyasasını tasarruf, yatırım, üretim ve milli gelir gibi makroekonomik değişkenler aracılığıyla etkilemektedir. Yüksek faiz oranı hane halklarının tasarruflarını artııırken yatırım amaçlı konut talebini daraltmaktadır (Öztürk ve Fitöz, 2009: 27).”

Konut piyasasının seyrini etkileyen değişkenler arası ilişkilere bağlı olarak inşaat ve gayrimenkul sektörünün büyümesi, hükümetin ilgili bakanlık ve kurumlar aracılı̆̆ıyla yürüttüğü politikalara, Merkez Bankası'nın faiz kararına, devlet ve özel bankaların konut kredisi kullandırma gücüne ve döviz kuru gibi faktörlere bağlıdır. Özellikle 2020 yılında tüm dünyayı etkisi altına alan Covid-19 salgını, dünya ve ülkemizde ciddi ekonomik belirsizlik ve durgunluğun yaşanmasına neden olmuştur. Bu küresel salgın, gayrimenkul ve inşaat sektörü üzerinde de etkisini göstermiş, ancak erken toparlanma dönemine girmiştir.

2021 y1lı dahil Emlak Konut GYO'nun halihazırda devam ettiği ve tamamlanan projeleri Tablo 8 ve 9'da proje adı, il, ilçe ve özellikleri ile sunulmaktadır.

Tablo 8: Emlak konut GYO’nun devam eden projeleri

\begin{tabular}{|c|c|c|c|}
\hline Proje Adı & İl & İlçe & Bă̆ımsız Bölüm (Konut+Ticari Alan) \\
\hline Semt Bahçekent 2. Etap & İstanbul & Başakşehir & 187 konut ve 20 ticari ünite \\
\hline $\begin{array}{c}\text { Emlak Konut Florya } \\
\text { Evleri }\end{array}$ & İstanbul & Bakırköy & 182 konut, 60 villa, 12 ticari alan \\
\hline $\begin{array}{c}\text { Avrasya Konutları } \\
\text { Bahçeşehir }\end{array}$ & İstanbul & Bahçeşehir & 453 konut \\
\hline
\end{tabular}




\begin{tabular}{|c|c|c|c|}
\hline Karat 34 & İstanbul & Bahçelievler & 470 konut, 151 ticari alan ( 123 ofis ve 28 dükkan) \\
\hline $\begin{array}{l}\text { Bizim Mahalle 1. Etap } 1 . \\
\text { Kisim }\end{array}$ & İstanbul & Küçükçekmece & 569 konut, 107 ticari alan \\
\hline Düşler Vadisi & İstanbul & Beykoz & 509 konut \\
\hline $\begin{array}{l}\text { Bizim Mahalle 1. Etap } 2 . \\
\text { Kisim }\end{array}$ & İstanbul & Küçükçekmece & 670 konut, 113 ticari alan \\
\hline İdealist Cadde & İstanbul & Şile & 45 konut, 13 ticari alan \\
\hline İdealist Koru & İstanbul & Şile & $\begin{array}{c}6 \text { adet } 1+1,40 \text { adet } 2+1,10 \text { adet } 3+1 \text { Bahçe } \\
\text { Dublex ve } 12 \text { adet Triplex İkiz Villa }\end{array}$ \\
\hline Nidapark İstinye & İstanbul & Sariyer & 538 bağımsız bölüm \\
\hline Ebruli Ispartakule & İstanbul & Avcilar & 724 konut, 52 ticari alan \\
\hline İstanbul Finans Merkezi & İstanbul & Ümraniye & --- \\
\hline Ormanköy & İstanbul & Çekmeköy & $-\cdots$ \\
\hline Cer İstanbul & İstanbul & Fatih & 125 konut, 23 ticari alan \\
\hline Nidapark Küçükyalı & İstanbul & Maltepe & $\begin{array}{c}1,159 \text { konut, } 851 \text { ticari alan (769 ofis ve } 82 \\
\text { dükkân) }\end{array}$ \\
\hline Semt Bahçekent 1. Etap & İstanbul & Başakşehir & 669 konut, 26 ticari alan \\
\hline Avrupark Hayat & İstanbul & Başakșehir & 1095 konut, 81 ticari alan \\
\hline TEM 34 Tahtakale & İstanbul & Avcilar & $\begin{array}{l}30 \text { bin metrekare alanda } 60 \text { ile } 10.000 \text { metrekare } \\
\text { arasında değişen üretim ve depolama alanları }\end{array}$ \\
\hline Köy Zekeriyaköy 1. Etap & İ̀stanbul & Sarıyer & $\begin{array}{c}\text { Proje genelinde toplam } 3 \text { etapta yaklaşık } 1.167 \\
\text { konut ve yaklaşı } 15.000 \mathrm{~m} 2 \text { bir alanda yeme, } \\
\text { içme, eğlence ve alıveriş imkânları sunan, } \\
\text { Çarşı̈öy ve } 118.000 \mathrm{~m} 2 \text { doğal koruluk alan yer } \\
\text { almaktadır. }\end{array}$ \\
\hline Köy Zekeriyaköy & İstanbul & Sariyer & 417 konut \\
\hline Avangart İstanbul & İstanbul & Kağıthane & 935 konut, 22 ticari alan \\
\hline $\begin{array}{l}\text { Yeniköy Konakları } \\
\text { İstanbul }\end{array}$ & İstanbul & Eyüp & 336 konut \\
\hline Ofis Karat Bakırköy & İstanbul & Bakırköy & 72 ticari alan \\
\hline Validebağ Konakları & İstanbul & Üsküdar & 319 konut, 48 ticari alan \\
\hline $\begin{array}{l}\text { Kuzey Yakası Cadde } \\
\text { Dükkanları } \\
\end{array}$ & İstanbul & Başakşehir & 400 ticari alan (350 ofis ve 50 dükkan) \\
\hline Nidapark Kayaşehir & İstanbul & Başakşehir & 843 konut, 28 ticari alan \\
\hline Büyükyalı İstanbul & İstanbul & Zeytinburnu & 1,481 konut \\
\hline Tual Bahçekent & İstanbul & Başakşehir & 2000 konut ve ticari alan \\
\hline Merkez Ankara & Ankara & Merkez & 2,020 konut, 1,210 ticari alan \\
\hline Başkent Emlak Konutları & Ankara & Çankaya & 478 konut, 26 ticari alan \\
\hline Koordinat Çayyolu & Ankara & Çankaya & 427 konut \\
\hline İzmir Alsancak & İzmir & Konak & 1069 konut, 37 ticari alan \\
\hline Evora İzmir & İzmir & Konak & 1049 konut, 41 ticari alan \\
\hline Gebze Emlak Konutları 3 & Kocaeli & Gebze & 1955 konut \\
\hline Temaşehir & Konya & Meram & 740 konut, 163 ticari alan \\
\hline Evora Denizli & Denizli & Merkez & $\begin{array}{c}\text { Yaklaşık 1,500 konut, } 2 \text { eğitim ve } 2 \text { ticaret } \\
\text { parseline sahip }\end{array}$ \\
\hline
\end{tabular}

Kaynak: www.emlakkonut.com.tr

Devam eden projelerin büyük bir kısmı Türkiye'nin en büyük kenti olan İstanbul'da bulunmaktadır. Ayrıca kurum, Ankara, İzmir, Kocaeli, Konya ve Denizli gibi diğer metropoliten illerde de yer seçiminde bulunup prestijli projeler üreterek kentlerin gelişimine, ekonomisine ve görünümüne katkı sağlamaktadır. Tamamlanan projelere bakıldığı zaman ilk sırada, devam eden projelerde olduğu gibi sermayenin merkezi konumunda olan İstanbul karşımıza çıkmaktadır. Bu ilin hem Avrupa hem de Asya yakasında bulunan birçok ilçesinde projelerin devam ettiği ve tamamlandığı görülmektedir. İstanbul'un dışında, Ankara, İzmir, Kocaeli, Konya, Tekirdağ, Kırklareli, Niğde ve Nevşehir gibi diğer 
Anadolu illerinde de projelerin tamamlandığ 1 görülmektedir. Emlak Konut GYO projelerini birçok merkez ilçede etaplar halinde sürdürülmüş ve sadece konut niteliğinin dışında finans merkezi, ticari alan, ofis, otel, eğitim kurumları ve sosyal tesisler şeklinde karma kullanıma yönelik tasarımlar geliştirmiştir.

Tablo 9: Emlak konut GYO’nun tamamlanan projeleri

\begin{tabular}{|c|c|c|c|}
\hline Proje Adı & il & İlçe & Bağımsız Bölüm (Konut+Ticari Alan) \\
\hline Bulvar 216 & İstanbul & Ataşehir & $\begin{array}{l}\text { Alışveriş merkezi, mağaza, restoran, cafe ve } \\
\text { aktivite alanları }\end{array}$ \\
\hline Nidakule Ataşehir & İstanbul & Ataşehir & --- \\
\hline Uphill Court Ataşehir & İstanbul & Ataşehir & 1742 konut \\
\hline Varyap Meridian & İstanbul & Ataşehir & 1500 konut, 5 yıldızlı otel ve ofisler \\
\hline 1stanbul Ispartakule & İstanbul & Avcilar & 1.188 konut \\
\hline $\begin{array}{c}\text { Emlak Konut Ispartakule } \\
\text { Evleri }\end{array}$ & İstanbul & Avcılar & 1849 konut \\
\hline Bizim Evler 2 & İstanbul & Avcilar & 520 konut \\
\hline Bizim Evler 3 & İstanbul & Avcılar & 2000 'e yakın konut \\
\hline Bizim Evler 4 & İstanbul & Avcılar & $\begin{array}{c}780 \text { konut, } 30 \text { ofis, } 2 \text { katlı dershane ve } 70 \\
\text { mağazalık Bizim Çarş1 }\end{array}$ \\
\hline My Town Ispartakule & İstanbul & Avcılar & 583 konut \\
\hline Unikonut Ispartakule & İstanbul & Avcılar & --- \\
\hline Ataşehir Residence & İstanbul & Ataşehir & 180 daire, 7 ofis ve 1 sosyal tesis \\
\hline Metropol İstanbul & İstanbul & Ataşehir & 1500 bağımsız ünite \\
\hline My Towerland & İstanbul & Ataşehir & 420 konut \\
\hline My World Ataşehir & İstanbul & Ataşehir & 3636 konut \\
\hline Avrupa Konutları - Tem & İstanbul & Gaziosmanpaşa & 2.824 konut \\
\hline Avrupa Konutları - Tem 2 & İstanbul & Gaziosmanpaşa & 414 konut ve 34 ticari alan \\
\hline Avrupa Konutları Atakent 3 & İstanbul & Küçükçekmece & 2300 konut ve 167 odalı bir hotel \\
\hline Dumankaya Miks & İstanbul & Küçükçekmece & $\begin{array}{c}657 \text { konut, } 72 \text { ticari alan, } 7 \text { ofis ve } 736 \\
\text { bağımsız bölüm }\end{array}$ \\
\hline Elite City & İstanbul & Küçükçekmece & 591 konut \\
\hline Soyak Park Aparts & İstanbul & Küçükçekmece & 2200 konut \\
\hline Karat 34 & İstanbul & Bahçelievler & 470 konut, 123 ofis ve 28 ticari \\
\hline Gölpanorama Evleri & İstanbul & Bahçeşehir & 1.431 konut ve 40 ticari alan \\
\hline Novus Residence & İstanbul & Bakırköy & 285 konut \\
\hline Ofis Karat Bakırköy & İstanbul & Bakırköy & 90 ofis ve dükkan \\
\hline Ispartakule & İstanbul & Başakşehir & 6000 konut \\
\hline $\begin{array}{c}\text { Avrupa Konutları } \\
\text { Başakşehir }\end{array}$ & İstanbul & Başakşehir & 941 konut ve 27 ticari alan \\
\hline $\begin{array}{l}\text { Avrupa Konutları } \\
\text { Ispartakule } 1\end{array}$ & İstanbul & Başakşehir & 385 konut ve 16 ticari alan \\
\hline $\begin{array}{l}\text { Avrupa Konutları } \\
\text { Ispartakule } 2 \\
\end{array}$ & İstanbul & Başakşehir & 330 konut \\
\hline $\begin{array}{l}\text { Avrupa Konutları } \\
\text { Ispartakule } 3\end{array}$ & İstanbul & Başakşehir & 644 konut ve 12 ticari alan \\
\hline Avrupark Bahçekent & İstanbul & Başakşehir & 1.394 konut ve 86 ticari alan \\
\hline Ayazma Emlak Konutları 1 & İstanbul & Başakşehir & --- \\
\hline Ayazma Emlak Konutları 2 & İstanbul & Başakşehir & --- \\
\hline Bahçekent Emlak Konutları & İstanbul & Başakşsehir & $\begin{array}{c}506 \text { konut, } 282 \text { ticari alan, } 1 \text { ilköğretim } \\
\text { okulu, } 1 \text { kreş ve } 1 \text { cami }\end{array}$ \\
\hline $\begin{array}{c}\text { Emlak Konut Başakşehir } \\
\text { Evleri }\end{array}$ & İstanbul & Başakşehir & $\begin{array}{c}2599 \text { konut, } 74 \text { ticari alan ve } 1 \text { ilköğretim } \\
\text { okulu }\end{array}$ \\
\hline Emlak Konut Başakşehir & İstanbul & Başakşehir & 271 konut \\
\hline
\end{tabular}




\begin{tabular}{|c|c|c|c|}
\hline Evleri 2 & & & \\
\hline Bahçekent Flora & İstanbul & Başakşehir & 875 konut ve ticari alan \\
\hline Bahçetepe İstanbul & İstanbul & Başakşehir & 1476 yaşam ünitesi \\
\hline Bulvar İstanbul & İstanbul & Başakşehir & 1555 konut \\
\hline Evvel - Adım İstanbul & İstanbul & Başakşehir & 673 konut \\
\hline Merkez Kayaşehir & İstanbul & Başakşehir & $\begin{array}{l}172 \text { mağaza, } 146 \text { odalı otel ve } 8 \text { salonlu } \\
\text { sinema }\end{array}$ \\
\hline Misstanbul Evleri & İstanbul & Başakşehir & 936 konut \\
\hline My World Europe & İstanbul & Başakşehir & 3060 konut ve 47 dükkan \\
\hline Park Mavera & İstanbul & Başakşehir & 670 konut \\
\hline Seyranşehir & İstanbul & Başakşehir & 220 konut \\
\hline Spradon Quartz & İstanbul & Başakşehir & 1045 konut \\
\hline Spradon Vadi & İstanbul & Başakşehir & 1037 konut \\
\hline Kent Plus Mimar Sinan & İstanbul & Büyükçekmece & 660 konut \\
\hline Esenler Emlak Konutları & İstanbul & Esenler & 2373 konut ve 55 ticari alan \\
\hline İstmarina & İstanbul & Kartal & 1463 konut ve 258 bağımsız bölüm \\
\hline Tual Adalar & İstanbul & Kartal & --- \\
\hline Maslak 1453 İstanbul & İstanbul & Sariyer & 4147 konut \\
\hline Selimpaşa Emlak Konutları & İstanbul & Silivri & 820 konut \\
\hline Sultanbeyli Emlak Konutları & İstanbul & Sultanbeyli & 436 konut \\
\hline Kuasar İstanbul & İstanbul & Şişli & $\begin{array}{l}257 \text { stüdyo, simpleks, dubleks daire, } 58 \text { ofis } \\
\text { ve } 28 \text { ticari alan }\end{array}$ \\
\hline $\begin{array}{c}\text { Evora İstanbul } \\
\text { Evora İstanbul Marmara }\end{array}$ & İstanbul & Tuzla & $\begin{array}{l}\text { 4.304 konut, ticaret ve alışveriş } \\
\text { bölgelerinden oluşmaktadır. }\end{array}$ \\
\hline Soyak Evostar & İstanbul & Tuzla & 1000 konut \\
\hline Tuzla Emlak Konutları 1 & İstanbul & Tuzla & 666 konut, 8 ticari alan ve 1 sosyal tesis \\
\hline Tuzla Emlak Konutları 2 & İstanbul & Tuzla & 1679 konut, 4 ticari alan ve 1 sosyal tesis \\
\hline Alemdağ Emlak Konutları & İstanbul & Ümraniye & 1192 konut ve 8 adet ticari alan \\
\hline Sarphan Finanspark & İstanbul & Ümraniye & Ofis, dükkan ve hotel bulunmaktadır. \\
\hline Şehrizar Konakları & İstanbul & Üsküdar & 208 bağımsız bölüm \\
\hline Başkent Emlak Konutları & Ankara & Çankaya & $\begin{array}{c}\text { Konut ve } 48.000 \mathrm{~m}^{2} \text { park alanı, } 1 \text { adet cami, } \\
\text { kapalı otopark1, } 1 \text { adet ilköğretim okulu ve } 1 \\
\text { adet sağlık tesisi }\end{array}$ \\
\hline Koordinat Çayyolu & Ankara & Çankaya & 427 konut \\
\hline Sofa Loca & Ankara & Etimesgut & 150 konut \\
\hline Batışehir & İstanbul & Bağcilar & --- \\
\hline Burgazkent & Kurklareli & Lüleburgaz & 752 daire ve 52 villa \\
\hline Dreamcıty Çerkezköy & Tekirdağ & Çerkezköy & 204 konut \\
\hline Yildıkent & Tekirdağ & Çerkezköy & 1160 konut, 1 ilköğretim okulu \\
\hline $\begin{array}{c}\text { Emlak Konut Mavişehir } \\
\text { Evleri }\end{array}$ & İzmir & Karşıyaka & 696 konut \\
\hline Emlak Konut Pelikan Sitesi & İzmir & Karşıyaka & 536 konut \\
\hline Mavişehir Modern & İzmir & Karşıyaka & 316 konut \\
\hline Park Yaşam Mavişehir & İzmir & Karşıyaka & 521 konut \\
\hline Soyak Mavişehir & İzmir & Karşıyaka & 1568 konut \\
\hline Ergene Vadisi & Tekirdağ & Çorlu & 1296 konut ve 76 ticari alan \\
\hline Gebze Emlak Konutları 1 & Kocaeli & Gebze & 524 konut ve 11 ticari alan \\
\hline Gebze Emlak Konutları 2 & Kocaeli & Gebze & 818 konut \\
\hline Körfezkent 1 & Kocaeli & Körfez & 3500 konut \\
\hline Körfezkent 2 & Kocaeli & Körfez & 791 konut \\
\hline Körfezkent 3 & Kocaeli & Körfez & 776 konut ve 11 ticari alan \\
\hline Körfezkent 4 & Kocaeli & Körfez & --- \\
\hline Körfezkent Çarşı & Kocaeli & Körfez & $\begin{array}{l}16 \text { cadde dükkanı, } 21 \text { meydan dükkanı ve } 66 \\
\text { ofis }\end{array}$ \\
\hline Nevşehir Emlak Konutları & Nevşehir & Merkez & 346 konut ve 74 ticari alan \\
\hline Niğde Emlak Konutları & Niğde & Merkez & 349 konut ve 16 mağaza \\
\hline Temaşehir Konya & Konya & Meram & 740 konut ve 163 mağaza \\
\hline
\end{tabular}

Kaynak: www.emlakkonut.com.tr 


\section{Sonuç}

Türkiye'de konut sektörünün önemi nüfus artış1, iç ve dış göçler, doğal afetler gibi nedenlerden dolayı her geçen gün artmaktadır. Kentleşme sürecini etkileyen bu tarz olgular özellikle kent merkezlerinde yaşanan konut sıkıntısını derinleştirmektedir. Konut sorununa çözüm bulmak ve insan onuruna yaraşır nitelikli ve konforlu bir yaşam alanı tasarlanmak önemli bir ihtiyaç olarak ortaya çıkmaktadır. Türkiye'de uzun yıllar konut sorununun çözümü için merkezi yönetim daha sonra da yerel yönetim ve özel sektör eliyle önemli çalışmalar yürütülmüştür. Çarpık yapılaşma ve mülkiyet sorunlarının çözülmesi için yasal mevzuatlar çıkarılmış ve sürecin hızlandırılması hedeflenmiştir. Başta TOKİ olmak üzere ilgili kurum ve kuruluşlar görevlendirilmiş ve gayrimenkul sektörünün gelişimi desteklenmiştir. 1980 sonrası dönemde neoliberal politikalar, ithal ikameci politikaların terkedilerek ihracat odaklı serbest piyasa ekonomisinin gelişmesi sağlamıştır. Küresel sermayenin ulus aşırı mekânlarda yatırıma yönelmesi kentsel arsa üzerinde değer artışına yol açmış ve özellikle metropoliten alanların gelişimini etkilemiştir. Bu süreç konut üretiminin önemini artırmış ve inşaat sektörünün ekonomik şoklardan etkilenmesini gidermek için finansal piyasalarla yapısal bir süreç içine girilmiştir. 1995 yılında SPK tarafından yasal düzenleme ile gayrimenkul sektöründe kurumsallaşmayı teşvik etmek için GYO’lar kurulmaya başlanmıştır.

Türkiye'deki GYO'lar içinde en yüksek piyasa değeri ve arsa stokunu elinde bulunduran Emlak Konut GYO'nun sermaye ve ortaklık payı büyük oranda TOKİ ve halka arz yoluyla sağlanmaktadır. Gelir paylaşım ve anahtar teslim modeli ile iş yapan GYO, 2020 yılında 131 bin bağımsız bölüm inşa etmiş ve 2023 yılı için 250 bin bağımsız bölüm hedefi belirlemiştir. Şirket, büyük çaplı projeler için arsa stokunun büyük bir kısmını TOKİ'den temin ederek çevreye duyarlı, nitelikli, orta ve orta-üst gelir grubuna yönelik konut projeleri üretimi gerçekleştirmektedir. Ayrıca proje dâhilinde kamu binaları, ticari alanlar ve sosyal donatı alanları da tasarlamaktadır. Hayata geçiren projeler metropoliten illerin dışında diğer Anadolu illerinde de yapılmaya başlanmış ve Türkiye'nin her bir bölgesinin çekim merkezi olma yolunda adımlar atılmıştır. Bu süreç Türkiye'de bir zorunluluk olarak görülen kentsel dönüşüm projelerini beraberinde getirerek merkezi-yerel yönetim ve özel sektör eliyle üretilen konut miktarının artırılmasına ve daha yaşanabilir ve konforlu konutların inşasına olanak tanımıştır. Kentlerin farklı dinamikleri içinde barındıran karmaşık yapısı, projeler açısından yer seçim sürecinde kentsel gelişimin yönünü belirlemeye katkı sağlamaktadır. Geliştirilen projelerdeki başarı düzeyi; yöre halkı, STK ve diğer paydaşların görüşlerinin alınarak katılımlarının sağlanmasını ve kullanıcı ihtiyaçlarını göz önüne alarak dönüşüm projelerinin gerçekleştirilmesi açısından önemlidir.

Bireyler, çevre ile uyumlu, karma kullanımın olduğu ve sosyal donatı alanlarıyla bütünleştirilmiş yaşam alanlarını öncelemekte ve bu unsurları içeren yerleşim yerlerini talep etmektedir. Bu bağlamda Emlak Konut GYO, sağlıklı, güvenli ve yaşanabilecek mekânlar üretmek, modern 
şehircilik prensiplerine sahip planlı, nitelikli ve çevreye duyarlı yerleşim yerleri inşa etmek amacıyla projeler geliştirmektedir. Emlak Konut GYO’nun büyük çaplı projelerinin daha sürdürülebilir ve uzun bir zaman dilimini kapsayan yaşanabilir ve çevre dostu alanların oluşturulmasını hedeflemesi kuruma olan güvenin sağlamlaşmasına ve piyasa değerinin artarak yeni projeler üretmesine imkan sağlamaktadır. Günümüzde tüm dünyayı etkisi altına alan küresel salgının özellikle insan yoğunluğunun olduğu kent merkezlerinde yaşamı kısıtlayıcı etkisinin, yaşanılan mekanda yeni normallere ve gelecekte yaşanabilecek muhtemel bulaşıcı hastalıklara göre proje tasarımlarında farklı prensiplerin de göz önünde bulundurulması gereğini gözler önüne sereceği aşikardır. Bu durum yaşanılan çağın şartlarına göre ekonomik, sosyal, çevresel ve kültürel etkilerini dikkate alarak dikey mimari yerine yatay mimarinin benimsendiği, insan yoğunluğunun azaltılarak açık ve yeşil alanların artırıldığı hem sağlıklı hem de sürdürülebilir projeler üretmede önemli unsurlar olduğunu göstermektedir.

Yazar Katkıları: Bu çalışmada yazarlar, iş birliği ve ortaklık içinde katkı sağlamıştır.

Çıkar Beyanı: Bu çalışmada yazarlar herhangi bir çıkar çatışması veya finansal destek bildirmemektedir.

\section{Kaynakça}

Çıkılı, G. (2010). Türkiye'de gayrimenkul sektörü ve gayrimenkul yatırım ortaklıkları (Yüksek Lisans Tezi). Dokuz Eylül Üniversitesi Sosyal Bilimler Enstitüsü, İzmir.

Çikot, Ö. (2011). Dünyada gayrimenkul yatırım ortaklıkları, sermaye piyasasında gündem. Türkiye Sermaye Piyasası Aracı Kuruluşları Birliği (Tspakb), 109, 23-32.

Dusuk1, A., W. (2008). Practice and prospect of islamic real estate investment trusts (I-Reits) in Malaysian Islamic Capital Market. Journal Of Islamic Economics, Banking And Finance, 6(2), 25. 40 .

Emlak Konut GYO (2018). Gayrimenkul ve konut sektörüne bakış, (Yazarlar: Bahadır Dalkılıç ve Mustafa Așkin), http://www.emlakkonut.com.tr/ assets/upload/1mages/file/yatirimci/sektorraporu/ekgyosektor-raporu-aralik-2018.pdf, (02.07.2020).

Emlak Konut GYO (2019). $2019 \quad$ Faaliyet Raporu. http://www.emlakkonut.com.tr/_assets/upload/1mages/file/yatirimci/faaliyetraporlari/tr/fr201 9trv4.pdf, (20.06.2020).

Emlak Konut GYO (2020). $2020 \quad$ Faaliyet Raporu. https://www.emlakkonut.com.tr/_assets/upload/1mages/file/yatirimci/faaliyetraporlari/tr/fr20 20tryay\%c4\%b1n05032021.pdf, (02.02.2021).

Epra (European Public Real Estate Association). Epra global reit survey-2019, https://prodapp.epra.com/media/epra_global_rett survey 2019_v8 1567517134733.0 intera ctive final.pdf, (22.06.2020).

Erol, T. ve Ozuturk, D., D. (2011). An alternative model of infrastructure financing based on capital markets: Infrastructure reits (Infrareits) in Turkey. Journal Of Economic Cooperation And Development, 32(3), 65-88.

Ey Global Real Estate, (2017). Global reit markets, ey building a better working world. https://www.ey.com/publication/vwluassets/ey-global-reit-markets/\$file/ey-global-reitmarkets.pdf (19.06.2020). 
Gayrimenkul Yatırım Ortaklıklarına İlişkin Esaslar Tebliği (Iı1-48.1). T.C. Resmi Gazete, 28660, 28 Mayis 2013.

GYODER (2014). 2014 yılı üç çeyrek verileri ile gayrimenkul sektörü. İstanbul: Gayrimenkul ve Gayrimenkul Yatırım Ortaklığı Derneği İktisadi İşletmesi, https://www.gyoder.org.tr/uploads/yay\%c4\%b1nlar/arastirma_raporlari/ar9.pdf (02.07.2020).

GYODER (2020). Gyoder gösterge, Türkiye gayrimenkul sektörü 2020 1.Çeyrek Raporu, 20, https://www.gyoder.org.tr/uploads/yayinlar/gosterge-ceyrek1-2020-web.pdf, (20.06.2020).

Kandır, Serkan Y. ve Özhan, Ecem, (2018). Gayrimenkul yatırım ortaklığı pay getirilerini etkileyen faktörlerin araştırılmas. BDDK Bankacılık ve Finansal Piyasalar, 12(2), 31-45.

Mazurczak, A. (2011). Development of real estate 1nvestment trust (reit) regimes in Europe, Journal Of International Studies, 4(1), 115-123.

Nuve Capital (2020). http://www.nuvecapital.com.tr/files/gyo\%20vs.\%20gyf\%20bulten.pdf, (17.06.2021).

Öztürk, T., E. ve Fitoz, D., D. (2009). An alternative model of infrastructure financing based on capital markets : Infrastructure reits (Infrareits) in Turkey. Journal Of Economic Cooperation And Development, 32(3), 65-88.

Pınar, C. (2019). Devletin konut sektörüne müdahalesinin emlak konut gayrimenkul yatırım ortaklığı üzerinden incelenmesi (Yüksek Lisans Tezi). Yıldız Teknik Üniversitesi Fen Bilimleri Enstitüsü, İstanbul.

SPK (2007). Gayrimenkul yatırım ortaklıkları, SPK yatırımcı bilgilendirme kitapçıkları-5, Ankara: Sermaye Piyasası Kurulu.

SPK (2021). https://www.spk.gov.tr/sayfa/altsayfa/409, (18.06.2021).

SPK (2021B). https://www.spk.gov.tr/sayfa/altsayfa/1212, (17.06.2021).

Tekşen, A. ve Zeynep, Y. (2019). Gayrimenkul yatırım ortaklıklarının islam iktisadı açısından incelenmesi (Yüksek Lisans Tezi). İstanbul Sabahattin Zaim Üniversitesi Sosyal Bilimler Enstitüsü, İstanbul.

TSKBGYO (2021).

http://www.tskbgyo.com.tr/yatirimciiliskileri/detay.aspx? section $1 \mathrm{~d}=\mathrm{mh} 32 \mathrm{~b} \% 2 \mathrm{fhjk} 38 \mathrm{hjkuolnxgeg} \% 3 \mathrm{~d} \% 3 \mathrm{~d} \&$ content $1 \mathrm{~d}=\mathrm{mh} 32 \mathrm{~b} \% 2$ fhjk38hjkuolnxgeg\%3d\%3d, (18.06.2021).

https://www.milliyetemlak.com/dergi/gayrimenkul-yatirim-ortakligi-nedir/, (18.06.2021).

http://www.emlakkonut.com.tr/tr-tr/hakkimizda, (20.06.2021).

https://www.emlakkonut.com.tr/tr-tr/projeler\#tamamlananprojeler, (12.05.2021).

http://www.emlakkonut.com.tr/tr-tr/projeler\#devamedenprojeler, (02.03.2021). 